\title{
Indium In 111 Anti-CD45 Monoclonal Antibody BC8
}

National Cancer Institute

\section{Source}

National Cancer Institute. Indium In 111 Anti-CD45 Monoclonal Antibody BC8. NCI

Thesaurus. Code C101522.

A radioimmunoconjug ate containing the murine IgG1 anti-CD45 monoclonal antibody (MoAb) BC8 labeled with the gamma-emitting isotope indium 111 (In 111), with potential radioimaging application. Upon administration, indium In 111 anti-CD45 monoclonal antibody BC8 binds to CD45 antigen, a receptor protein tyrosine phosphatase expressed on the surface of most of the normal and malignant hematopoietic cells. After binding and internalization by CD45-expressing tumor cells, radioactive In 111 allows for the detection of BC8 distribution and tumor localization using gamma scintigraphy. 